\title{
ANALISIS GETARAN AKIBAT MASSA YANG TIDAK SEIMBANG PADA MOTOR YANG BERPUTAR
}

\author{
Nanang Endriatno \\ Jurusan Teknik Mesin, Universitas Halu Oleo, Indonesia \\ nanangendriatno@gmail.com
}

\begin{abstract}
ABSTRAK
Tujuan dari penelitian ini adalah untuk mengetahui karekteristik perpindahan, kecepatan, dan percepatan getaran akibat peningkatan masa berputar yang tidak seimbang (unbalance mass) pada balok kantilever aluminium. Penelitian ini menggunakan metode eksperimental dengan memvariasikan massa tidak seimbang pada motor penggetar. Alat dan bahan yang digunakan dalam pengukuran langsung yaitu vibration meter, motor penggetar, balok aluminium seri 6061, dan tumpuan kantilever. Vibration meter digunakan untuk mengukur jarak perpindahan getaran, intensitas getaran atau kcepatan getaran, dan perubahan laju keceparan atau percepatan. Level getaran diukur pada dengan menambahkan massa tidak seimbang pada massa yang berputar dimotor pengetar dengan variasi penambahan massa sebesar: $1.2 \mathrm{gr}$, $1.56 \mathrm{gr}, 1.9 \mathrm{gr}, 2.29$ gr. Alat sensor getaran diletakkan diatas balok tumpuan dari motor penggetar. Hasil pengujian eksperimental getaran menunjukkan bahwa nilai perpindahan, kecepatan, dan percepatan meningkat ketika massa ditambahkan pada motor pada radius $15 \mathrm{~mm}$ dari poros motor. Penambahan massa tidak seimbang akan menyebabkan gaya eksitasi bertambah dan meningkatkan level getaran. Hasil pengukuran menunjukkan perpindahan getaran tertinggi pada massa $\left(\mathrm{m}_{4}\right): 2.29$ gr dengan nilai $0.72 \mathrm{~mm}$ dan terendah pada massa $\left(\mathrm{m}_{1}\right): 1.2$ gr dengan nilai: $0.09 \mathrm{~mm}$. Kecepatan getaran (v) tertinggi dengan nilai $181.55 \mathrm{~mm} / \mathrm{s}$ dan minimum pada $74.05 \mathrm{~mm} / \mathrm{s}$. Sedangkan percepatan getaran (a) tertinggi pada $175333 \mathrm{~mm} / \mathrm{s}^{2}$ dan terendah pada $132017 \mathrm{~mm} / \mathrm{s}^{2}$.
\end{abstract}

Kata kunci: getaran, massa tidak seimbang, aluminium, kantilever, motor

\begin{abstract}
Analysis of Unbalanced Mass Due Vibration of a Rotating Motor. The purpose of this study is to determine the characteristics of the displacement, velocity, and acceleration of vibrations due to an increase in unbalanced rotating mass (unbalance mass) at aluminum cantilever beams. This study used an experimental method by varying the unbalanced mass on a vibrating motor. The tools and materials used in direct measurement were vibration meter, exciter motor, 6061 series aluminum beam, and cantilever support Vibration meters was used to measure the distance of vibration displacement, the intensity of the vibration or the velocity of the vibration, and the change in vibration velocity or acceleration. The vibration level was measured by adding the unbalanced mass to the rotating mass in the motor shaking with the variation of the mass addition of: $1.2 \mathrm{gr}, 1.56 \mathrm{gr}, 1.9 \mathrm{gr}, 2.29 \mathrm{gr}$. The vibration sensor device was placed on the support beam of the vibrating motor. The results of the experimental vibration test showed that the values of displacement, velocity, and acceleration increase when mass were added to the motor at a radius of $15 \mathrm{~mm}$ from the motor shaft. The unbalanced addition of mass will cause the excitation force to increase and increase the level of vibration. The measurement results showed the highest vibration displacement at mass $\left(\mathrm{m}_{4}\right): 2.29 \mathrm{gr}$, with value 0.72 $\mathrm{mm}$ and the lowest at mass $\left(\mathrm{m}_{1}\right): 1.2 \mathrm{gr}$, with value: $0.09 \mathrm{~mm}$. The highest vibration speed $(\mathrm{v})$ is $181.55 \mathrm{~mm} / \mathrm{s}$ and the minimum is $74.05 \mathrm{~mm} / \mathrm{s}$. While the acceleration of vibration (a) is the highest at $175333 \mathrm{~mm} / \mathrm{s}^{2}$ and the lowest is at $132017 \mathrm{~mm} / \mathrm{s}^{2}$
\end{abstract}

Keywords: vibration, unbalanced mass, aluminum, cantilever, motor 


\section{PENDAHULUAN}

Analisis getaran dapat dilakukan pada mesin atau komponen bergerak atau berputar untuk mengetahui kondisi mekanis peralatan atau mesin. Pengukuran getaran ini memiliki kelebihan karena pengukurannya dilakukan tanpa membongkar atau merusak sistem peralatan dan disamping itu dapat mendeteksi kerusakan mesin sejak awal sehingga kerusakan yang besar dapat dihindari. Tingkat getaran hasil pengukuran dapat mendeteksi kerusakan pada mesin seperti mendeteksi kerusakan pada bantalan, komponen mesin yang kendor, roda gigi yang cacat. Pemantauan getaran dapat juga digunakan untuk mendeteksi tingkat getaran akibat ketidakseimbangan massa (unbalance mass) dan ketidaksejajaran poros (misalignment) yang menjadi penyebab timbulnya getaran. Pemantauan getaran bertujuan untuk menghindari terjadinya kerusakan yang serius yang menyebabkan kerusakan dan ketidaknyamanan [1].

Pengukuran getaran juga dapat digunakan untuk mengetahui pemeliharaan yang buruk seperti pemasangan dan penggunaan komponen mesin yang tidak sesuai seperti yang disebutkan diatas. Pemeliharan dapat dilakukan pada semua mesin yang bergerak bolak balik karena mesin-mesin akan menghasilkan getaran pada level tertentu yang merupakan sifat dinamik mesin itu sendiri [2].

Beberapa penelitian telah meneliti karakteristik getaran pada komponen mesin [3][4][5][6]. Penelitian tersebut meneliti level getaran pada kenderaan dan menyimpulkan bahwa dengan mengontrol kondisi mesin dan konstruksinya maka dapat meningkatkan kenyamanan dalam berkendara. Penelitian lain juga meneliti getaran untuk mengetahui tingkat kerusakan pada komponen mesin [7][8][9]. Dari penelitian tersebut ditemukan bahwa kerusakan komponen mesin seperti cacat pada bantalan, ketidak sejajaran poros dapat dideteksi dari level getaran yang dihasilkan. Getaran juga digunakan untuk penggetar pada alat-alat produksi [10][11]. Penelitian tersebut merancang alat produksi dengan memanfaatkan getaran dengan memodifikasi mekanisme gerak motor. Pada peralatan tertentu getaran dibutuhkan untuk mengoptimalkan produksi. Oleh karenanya itu penelitian tentang mekanisme terntentu dan level getaran yang dihasilkan menjadi penting karena akan berpengaruh pada optimalisasi produksi. Penelitian pada motor yang ditumpu kantilever telah diinvestigasi untuk mengetahui pengaruh struktur bahan terhasap kekakuan terhadap frekuensi yang dihasilkan [12]. Hasil penelitian ini menunjukkan bahwa selain faktor mekanis dari dalam mesin itu sendiri, faktor luar seperti kekakuan material dan struktur pendukungnya juga menentukan respon getaran yang terjadi.

Walaupun penelitian tentang respon getaran pada mesin telah dilakukan oleh beberapa peneliti, namun karena kompleksitas parameter getaran pada mesin, sehingga penelitian tentang getaran masih penting dilakukan utamanya mengenai penyebab getaran dan level getaran yang dihasilkan pada kondisi struktur dan peralatan tertentu. Getaran pada sistem harus dihindari jika mengakibatkan kerusakan pada komponen. Meskipun demikian pada peralatan tertentu seperti alat produksi pertanian, getaran diinginkan timbul pada sistem. Getaran tersebut dapat digunakan untuk mekanisme pengayakan ataupun mekanisme pengering.

Massa yang tidak seimbang pada mesin dapat menimbulkan getaran pada mesin. Hubungan antara massa yang tidak seimbang dan berapa besar level getaran yang dihasilkan pada struktur tertentu dengan kekakuan yang dimiliki bahannya perlu diinvestigasi lebih lanjut, utamanya korelasi antara massa tidak seimbang dengan tingkat getaran yang terjadi dan korelasi antara perpindahan, kecepatan, percepatan getarannya. SSehingga dari latar belakang diatas maka tujuan dari penelitian adalah untuk mengetahui karekteristik getaran yaitu: perpindahan, kecepatan, dan percepatan getaran akibat peningkatan masa berputar yang tidak seimbang pada balok kantilever aluminium.

\section{Analisis vibrasi}

Pemeliharaan mesin dengan teknik pemantauan level getaran dapat dilakukan baik secara kontinyu maupun secara berkala dengan jarak waktu tertentu. Pemantauan getaran bertujuan untuk mengidentifikasi perkembangan masalah sebelum masalah tersebut menjadi lebih berbahaya dan mempengaruhi sistem. Analisis getaran terutama dapat dilakukan pada komponen mesin yang berputar seperti kincir angin, motor listrik, motor bensin, motor diesel, bantalan, poros, roda gigi dan sebagainya. Tingkat level getaran pada komponen tersebut dapat berbeda dan ditentukan menurut 
karateristik dinamiknya masing-masing. Selain mendeteksi kerusakan pada komponen mesin, level getaran juga dapat mendeteksi pekerjaan produksi yang tidak tepat, seperti penggunaan peralatan diluar spesifikasi desain, penggunaan diluar ambang batas kekuatannnya, kemampuan menahan kondisi kerja (temperatur, kecepatan, beban, dan lain-lain). Pada ujungnya analisis getaran bertujuan untuk mengoptimalkan kehandalan peralatan atau sistem. Pada saat komponen mesin seperti bantalan, roda gigi, motor, sabuk, poros bekerja terus menerus dalam waktu yang lama maka peralatan tersebut akan mengalami ketidakseimbangan massa, kerusakan, cacat, yang lama kelamaan akan terus berkembang. Keadaan ini menimbulkan level getaran menjadi meningkat. Keparahan getaran ini akan menyebabkan umur peralatan menjadi lebih pendek karena peningkatan keausan dan tegangan, mengurangi kenyamanan, mengurangi kualitas produk, dan fungsi alat. Unbalance adalah kondisi getaran yang terjadi karena ketidakseimbangan massa yang berputar. Hal ini dapat terjadi Ketika massa yang berputar (rotor) tidak berada pada pusat perputaran dari poros. Kondisi ini mengakibatkan mesin bergetar. Penelitian ini difokuskan pada massa yang tidak seimbang. Pada gambar 1 terlihat sebuah massa berputar dengan kecepatan sudut $(\varpi)$ pada sebuah mesin dengan massa (m) dimana mesin tersebut berada disuatu tumpuan dengan kekakuan (k) dan koefisen redaman (c). Sebuah masa tidak seimbang $\left(\mathrm{m}_{\mathrm{i}}\right)$ berada pada bagian yang berputar dengan jarak jari-jari eksentrik dari pusat motor (e), massa tidak seimbang menyebabkan motor berputar menjadi tidak seimbang sehingga menimbulkan gaya eksitasi (F) yang diterima oleh mesin dan strukturnya [13].

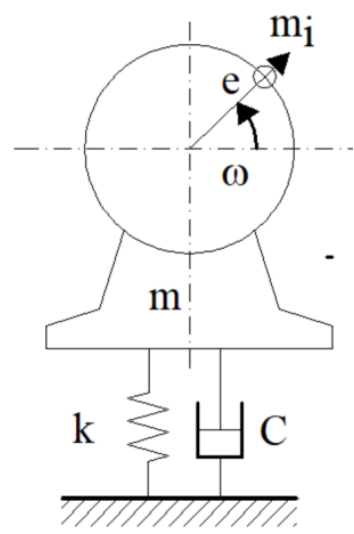

Gambar 1. Massa berputar dan bolak balik yang tidak seimbang
Persamaan gaya eksitasi untuk masa berputar dan bolak balik yang tidak seimbang adalah sebagai berikut:

$F=m_{0} \cdot e \cdot \varpi^{2}$

Dimana:

$\mathrm{f}$ = gaya eksitasi $(\mathrm{N})$

$\mathrm{m}_{0}=$ massa yang tidak seimbang $(\mathrm{Kg})$

$\mathrm{e}=$ Jari-jari eksentrik $(\mathrm{m})$

$\varpi=$ kecepatan sudut $(\mathrm{rad} / \mathrm{det})$

Kecepatan sudut dihitung dengan persamaan:

$\varpi \quad=\frac{2 \pi n}{60}$

Dimana:

$\mathrm{n}=$ putaran motor $(\mathrm{rpm})$

\section{Aluminium seri 6061}

Aluminium memiliki ketahanan korosi yang sangat baik hal ini yang menyebabkan bahan ini banyak digunakan dalam aplikasi struktural otomotif. Sebagai bahan alternatif dari baja, penggunaan aluminium dapat menghemat konsumsi bahan bakar sebagai dampak dari bobotnya yang ringan. Penggunaan aluminium pada bagian kenderaan seperti piston, silinder blok, dan komponen lain yang beban kerjanya pada temperatur tinggi menyebabkan bahan ini harus dipadukan dengan bahan lain salah satunya aluminium seri 6061 [14] [15].

Penelitian menggunaan bahan Aluminium seri 6061. Standar komposisi kimia dari bahan ini diberikan pada Tabel 1, sedangkan sifat mekaniknya dilihat pada Tabel 2 [16].

Tabel 1. Komposisi kimia dari paduan Aluminium 6061 (Wt.\%).

\begin{tabular}{l|l}
\hline Unsur & Persentase berat (\%) \\
\hline $\mathrm{Mg}$ & $0.8-1.2$ \\
$\mathrm{Si}$ & $0.4-08$. \\
$\mathrm{Mn}$ & 0.15 \\
$\mathrm{Fe}$ & 0.7 \\
$\mathrm{Cr}$ & $0.04-0.35$ \\
$\mathrm{Zn}$ & 0.25 \\
$\mathrm{Ti}$ & 0.15 \\
$\mathrm{Cu}$ & $0.15-0.4$ \\
\hline
\end{tabular}


Sumber [16]

Tabel 2. Sifat Mekanik dari paduan Aluminium seri 6061.

\begin{tabular}{l|c}
\hline \multicolumn{1}{c|}{ Sifat Mekanik } & Aluminium 6061 \\
\hline Kekuatan Tarik Maks. (MPa) & 283 \\
Tegangan luluh (MPa) & 265 \\
Modulus Elastis (GPa) & 64 \\
Koefisien Kekuatan (MPa) & 416 \\
\hline
\end{tabular}

Sumber [16]

\section{Pengukuran Getaran}

Pengukuran getaran dapat dilakukan dengan bantuan alat vibration meter yang dapat digunakan untuk mengukur perpindahan getaran $(\mathrm{d}, \mathrm{mm})$, kecepatan getaran $(\mathrm{v}, \mathrm{cm} / \mathrm{s})$, dan percepatan getaran $\left(\mathrm{a}, \mathrm{m} / \mathrm{s}^{2}\right)$. Perpindahan getaran adalah jarak yang ditempuh oleh bagian yang bergetar yang besarnya setengah dari peak to peak (m). Kecepatan getaran biasa dinyatakan dalam $\mathrm{m} / \mathrm{s}$ (peak) yang merupakan indikator dari kecepatan puncak (velocity peak) yang berkorelasi dengan intensitas getaran. Percepatan getaran didefinisikan sebagai laju perubahan kecepatan dinyatakan dalam $\mathrm{m} / \mathrm{s}^{2}$. Karakteristik getaran seperti perpindahan, kecepatan, dan percepatan getaran digunakan untuk mengukur level getaran. Dari karakteristik getaran maka dapat diketahui respon dinamis dari mesin atau mekanisme yang dapat digunakan sebagai penilaian pertama dari sebuah mesin sebelum dilakukan pembongkaran, pemasangan ulang atau penggantian komponen. Pemantau kondisi mesin dapat menggunakan 3 parameter getaran ini (perpindahan, kecepatan, dan percepatan) secara bersamaan ataupun digunakan salah satunya dalam rentang frekuensi tertentu. Dalam penelitian ini 3 parameter ini diukur untuk mengetahui perbedaanya kemudian dilihat korelasinya masing-masing [1].

\section{METODE}

\section{Metode Penelitian}

Penelitian ini dilakukan dengan metode eksperimental di Laboratorium Desain dan Konstruksi Mesin Universitas Halu Oleo. Peralatan yang digunakan dalam penelitian ini adalah alat pengukur getaran (Type KW0600332 Vibration Tester), motor penggetar massa tidak seimbang, balok aluminium seri 6061 dengan Panjang balok (l): $60 \mathrm{~cm}$, lebar balok (b): $2,9 \mathrm{~cm}$, tebal balok (t): $0,9 \mathrm{~cm}$, dan timbangan digital seperti ditunjukkan pada gambar 4.

\section{Prosedur Pengukuran getaran}

Batang aluminium ditempatkan pada tumpuan kantilever (jepit-bebas), pada ujung bebas dari balok ditempatkan sebuah motor penggetar $(n=6000 \mathrm{rpm})$ yang dapat diatur massa tidak seimbangnya. Pengujian dilakukan dengan memvariasikan 4 buah massa tidak seimbang yaitu: $\mathrm{m}_{1}=1.2 \mathrm{gr}, \mathrm{m}_{2}=1.56 \mathrm{gr}$, $\mathrm{m}_{3}=1.91$ gr, $\mathrm{m}_{4}=2.29$ gr. Massa tidak seimbang dapat dilihat pada gambar 3. Sensor getaran dari alat vibration meter diletakkan didekat motor penggetar d. Posisi sensor getaran diletakkan pada atas balok untuk membaca lever getaran vertikal. Pengujian dilakukan mulai dari massa tidak seimbang pertama $\left(\mathrm{m}_{1}\right)$ sampai keempat $\left(\mathrm{m}_{1}\right)$ pada putaran motor konstan dan pada balok aluminium seri 6061 yang ditumpu kantilever. Selama pengujian sensor getaran membaca perpindahan, kecepatan, dan percepatan getaran yang dihasilkan. Skema instalasi pengujian getaran dapat dilihat pada gambar 2 .

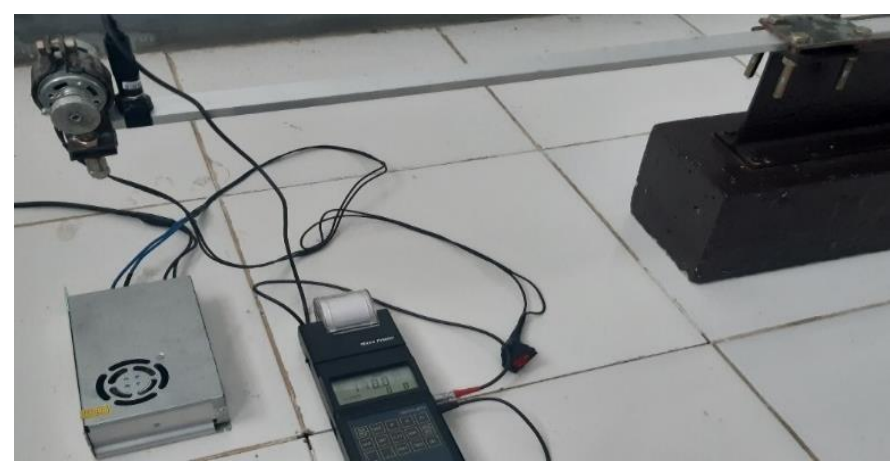

Gambar 2. Instalasi pengujian massa tidak seimbang
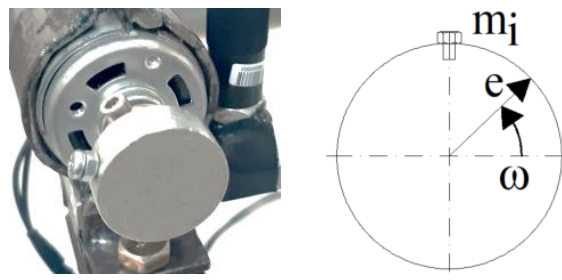

Gambar 3. Posisi massa tidak seimbang pada motor 


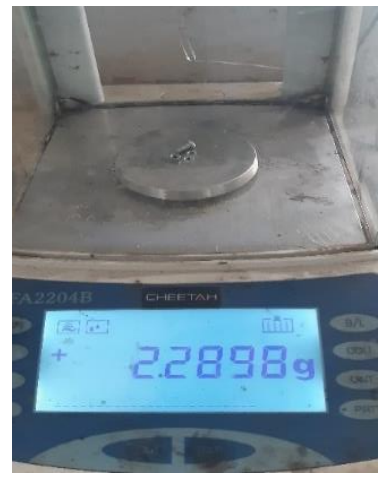

Gambar 4. Pengukuran massa tidak seimbang dengan timbangan digital

\section{HASIL DAN PEMBAHASAN}

Pengukuran level getaran untuk perpindahan, kecepatan, dan percepatan dilakukan pada setiap massa tidak seimbang sebanyak 6 kali. Hasil pengujian getaran dapat dilihat pada tabel 3, 4, dan 5. Sedangkan kumpulan nilai rata-ratanya ditunjukkan pada tabel 6 .

Tabel 3. Tabel pengukuran perpindahan getaran pada tiap massa tidak seimbang.

\begin{tabular}{c|c|c|c|c}
\hline \multirow{2}{*}{ Data } & \multicolumn{4}{|c}{ Perpindahan getaran $(\mathbf{m m})$} \\
\cline { 2 - 5 } & $\mathbf{m}_{\mathbf{1}}$ & $\mathbf{m}_{\mathbf{2}}$ & $\mathbf{m}_{\mathbf{3}}$ & $\mathbf{m}_{\mathbf{4}}$ \\
\hline 1 & 0.11 & 0.13 & 0.41 & 0.61 \\
2 & 0.11 & 0.12 & 0.33 & 0.78 \\
3 & 0.07 & 0.31 & 0.51 & 0.71 \\
4 & 0.08 & 0.21 & 0.61 & 0.75 \\
5 & 0.07 & 0.21 & 0.45 & 0.75 \\
6 & 0.08 & 0.29 & 0.51 & 0.71 \\
\hline Rata-rata $(\mathrm{mm})$ & 0.09 & 0.21 & 0.47 & 0.72 \\
\hline
\end{tabular}

Tabel 4. Tabel pengukuran kecepatan getaran pada tiap massa tidak seimbang.

\begin{tabular}{c|c|c|c|c}
\hline \multirow{2}{*}{ Data } & \multicolumn{4}{|c}{ Kecepatan getaran $(\mathbf{c m} / \mathbf{s})$} \\
\cline { 2 - 5 } & $\mathbf{m}_{\mathbf{1}}$ & $\mathbf{m}_{\mathbf{2}}$ & $\mathbf{m}_{\mathbf{3}}$ & $\mathbf{m}_{\mathbf{4}}$ \\
\hline 1 & 7.28 & 9.13 & 10.41 & 18.11 \\
2 & 7.61 & 9.08 & 9.49 & 18.11 \\
3 & 7.11 & 8.67 & 9.54 & 18.15 \\
4 & 7.22 & 8.54 & 9.81 & 18.18 \\
5 & 7.55 & 8.86 & 9.61 & 18.19 \\
6 & 7.66 & 8.86 & 9.99 & 18.19 \\
\hline Rata-rata $(\mathrm{cm} / \mathrm{s})$ & 7.41 & 8.86 & 9.81 & 18.16 \\
\hline Rata-rata $(\mathrm{mm} / \mathrm{s})$ & 74.05 & 88.57 & 98.08 & 181.55 \\
\hline
\end{tabular}

Tabel 5. Tabel pengukuran percepatan getaran pada tiap massa tidak seimbang.

\begin{tabular}{c|c|c|c|c}
\hline \multirow{2}{*}{ Data } & \multicolumn{4}{|c}{ Pecepatan getaran $\left(\mathbf{m} / \mathbf{s}^{\mathbf{2}}\right)$} \\
\cline { 2 - 5 } & $\mathbf{m}_{\mathbf{1}}$ & $\mathbf{m}_{\mathbf{2}}$ & $\mathbf{m}_{\mathbf{3}}$ & $\mathbf{m} \mathbf{4}$ \\
\hline 1 & 130 & 150 & 168.2 & 174.1 \\
2 & 132 & 147.8 & 157.1 & 177.1 \\
3 & 134.7 & 143 & 157.1 & 177.1 \\
4 & 132.1 & 145.1 & 167.1 & 174.1 \\
5 & 133.2 & 145.2 & 160.1 & 174.1 \\
6 & 130.1 & 147.3 & 160.1 & 175.5 \\
\hline Rata-rata & & & & \\
$\left(\mathrm{m} / \mathrm{s}^{2}\right)$ & 132.02 & 146.40 & 161.62 & 175.33 \\
\hline Rata-rata \\
$\left(\mathrm{mm} / \mathrm{s}^{2}\right)$ & 132017 & 146400 & 161617 & 175333 \\
\hline
\end{tabular}

Tabel 6. Tabel rata-rata hasil pengukuran perpindahan, kecepatan, dan percepatan getaran.

\begin{tabular}{c|c|c|c}
\hline \multirow{2}{*}{$\begin{array}{c}\text { massa tidak } \\
\text { seimbang }\end{array}$} & \multicolumn{3}{|c}{ Nilai Rata-rata Getaran } \\
\cline { 2 - 4 } $\mathbf{~ m ~ ( g r ) ~}$ & Perpindahan & Kecepatan & Percepatan \\
\hline $\mathrm{m}_{1}=1.20$ & 0.09 & $\mathbf{v}(\mathbf{m m} / \mathbf{s})$ & $\mathbf{a}\left(\mathbf{m m} / \mathbf{s}^{\mathbf{2}}\right)$ \\
$\mathrm{m}_{2}=1.56$ & 0.21 & 74.05 & 132017 \\
$\mathrm{~m}_{3}=1.91$ & 0.47 & 98.08 & 146400 \\
$\mathrm{~m}_{4}=2.29$ & 0.72 & 181.55 & 161617 \\
\hline
\end{tabular}

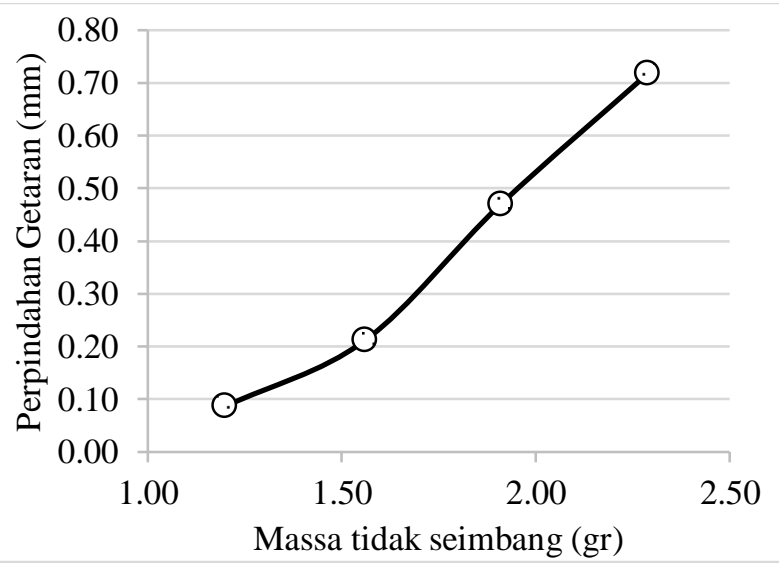

Gambar 5. Penambahan massa dan hasil pengukuran perpindahan getaran 


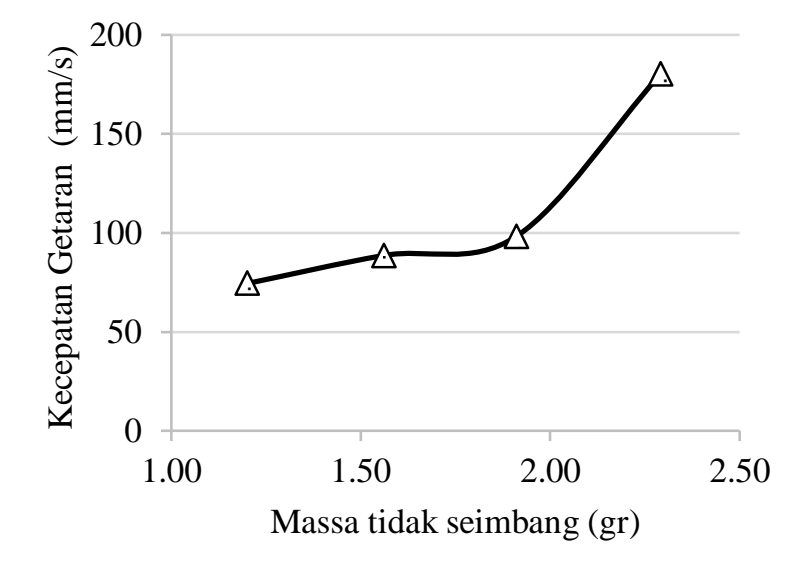

Gambar 6. Penambahan massa dan hasil pengukuran kecepatan getaran

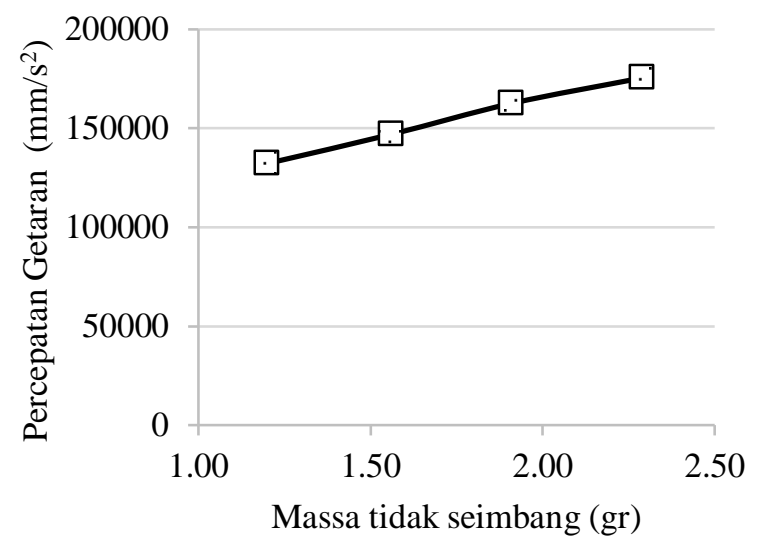

Gambar 7. Penambahan massa dan hasil pengukuran percepatan getaran.

Gambar 5, 6, dan 7 menunjukkan hasil pengukuran tingkat getaran dengan menggunakan 4 massa tidak seimbang. Secara umum nilai perpindahan, kecepatan, dan percepatan meningkat seiring dengan penambahan massa tidak seimbang. Ketiga nilai getaran ini dapat dibaca dengan baik oleh alat pengukur getaran dan memiliki perbedaan setiap kenaikan massanya. Secara teori pada putaran tertentu atau kondisi nilai perpindahan, kecepatan, dan percepatan dapat terbaca atau tidak dapat terbaca dan dianalisis secara bersamaan [1].

Gambar 5 dan tabel 6 menujukkan nilai perpindahan getaran yang meningkat dari nilai minimum 0,09 mm sampai mencapai nilai maksimumnya pada 0,72 mm. Peningkatan ini dicapai ketika massa ditambahkan dari 1,2 gr menjadi 2,29 gr atau selisih 1,09 gr dengan posisi masa tidak seimbang berada
$15 \mathrm{~mm}$ dari titik pusat putaran motor. Dari gambar 5 terlihat bahwa peningkatan terjadi setiap penambahan massa tidak seimbang. Hal ini menunjukkan bahwa penambahan massa tidak seimbang berdampak pada peningkatan level getaran khususnya perpindahan vertikal dari sistem. Ketika massa ditambahkan pada motor maka hal ini berpengaruh pada peningkatan gaya eksitasi (gaya penggetar) sesuai dengan persamaan 1. Beberapa faktor yang menentukan perpindahan getaran adalah massa total, posisi massa tidak seimbang dari pusat putaran motor, kekakuan balok, dan faktor redaman dari sistem [13]. Namun demikian parameter yang divariasikan dalam penelitian ini adalah massa tidak seimbang sedangkan parameter lain dibuat konstan. Sehingga dapat disimpulkan bahwa massa tidak seimbang berpengaruh terhadap level perpindahan getaran sistem.

Gambar 6 dan tabel 6 menunjukkan nilai kecepatan getaran dari sistem. Nilai kecepatan getaran memiliki kecenderungan yang sama dengan nilai perpindahan, dimana semakin besar massa tidak seimbang maka nilai kecepatan getaran juga meningkat. Kecepatan getaran meningkat dari nilai terendah $74,05 \mathrm{~mm} / \mathrm{s}$ pada $\mathrm{m}_{1}=1,2$ gr menjadi maksimum pada $\mathrm{m}_{4}=2,29$ gr yaitu $181,16 \mathrm{~mm} / \mathrm{s}$. Kecepatan getaran adalah indikator dari intensitas getaran yang dihasilkan. Semakin jauh jarak atau perpindahan yang ditempuh pada tiap satuan waktu maka nilai kecepatannya juga meningkat. Gambar 7 dan tabel 6 menunjukkan nilai percepatan dari sistem. Nilai percepatan minimum yaitu 132017 $\mathrm{mm} / \mathrm{s}^{2}$ pada pada $\mathrm{m}_{1}=1,2$ gr menjadi maksimum pada $\mathrm{m}_{4}=2,29$ gr yaitu $175333 \mathrm{~mm} / \mathrm{s}^{2}$. Percepatan getaran menunjukkan laju perubahan kecepatan dari getaran. Seperti diketahui bahwa getaran adalah gerak bolak balik pada posisi kesetimbangan tertentu. Perubahan kecepatan pada getaran terjadi karena setiap kali perambatan getaran berhenti dibatas perambatannya, maka perambatan akan berubah agar meningkatan kecepatan getarannya pada siklus yang selanjutnya. Dari penelitian ini menunjukkan nilai percepatan dan kecepatan meningkat seiring dengan peningkatan perpindahan getarnya dan ketiga parameter ini mempunyai korelasi dan keduanya dapat digunakan menjadi indikator dalam analisis level getaran dalam penelitian ini. 


\section{KESIMPULAN}

Dari hasil penelitian dapat ditarik kesimpulan bahwa peningkatan massa tidak seimbang pada motor meningkatkan gaya eksitasi dan menjadi penyebab timbulnya getaran pada sistem. Peningkatan gaya eksitasi mengakibatkan nilai perpindahan, kecepatan, dan percepatan meningkat. Peningkatan massa 1.09 gram pada radius $15 \mathrm{~mm}$ dari poros motor menyebabkan perpindahan meningkat dengan nilai maksimum pada $0.72 \mathrm{~mm}$, nilai kecepatan maksimum terjadi pada $181.55 \mathrm{~cm} / \mathrm{s}$, dan nilai percepatan maksimum yaitu $175.33 \mathrm{~m} / \mathrm{s}$.

\section{DAFTAR PUSTAKA}

[1] A. Hamid (2012). Praktikal Vibrasi Mekanik Teori dan Praktik, Yogyakarta: Graha Ilmu.

[2] Fundamentals of mechanical vibrations (1993). Choice Reviews Online, vol. 31, no. 01. pp. 310327-31-0327, doi: 10.5860/choice.31-0327.

[3] Finahari, N. (2003). Analisa Karakteristik Amplitudo Getaran Pada Mesin Silinder Tunggal. Sumber, 9(115), 0-25.

[4] Sari, J., \& Martianis, E. (2019). Analisa getaran footers (pijakan) pada sepeda motor non-matic dengan variasi kecepatan. In Seminar Nasional Industri dan Teknologi (pp. 129-138).

[5] Sadiana, R. (2016). Analisis Respon Sistem Getaran Pada Mesin Torak. Jurnal Ilmiah Teknik Mesin Unisma" 45" Bekasi, 4(2), 98382.

[6] Rinawati, S. (2013). Analisis Hubungan Paparan Getaran Mekanis dan Kebisingan dengan Kelelahan Kerja Pekerja Bagian Mesin Tenun di PT. Iskandar Indah Printing Textile Surakarta (Doctoral dissertation, UNS (Sebelas Maret University)).

[7] Suharjono (2004). Analisis Sinyal Getaran untuk Menentukan Jenis dan Tingkat Kerusakan Bantalan Bola (Ball Bearing)," J. Tek. Mesin, doi: 10.9744/jtm.6.2. pp. 39-48.

[8] Syahrul, M., Margianto, M., \& Lesmanah, U. (2017). Analisa getaran untuk mengetahui tingkat kerusakan bearing mesin gerinda duduk. Jurnal Teknik Mesin, 2(02).
[9] Raharjo, I. A., Widodo, A., \& Haryanto, I. (2016). Analisis Misalignment Kopling Pada Mesin Rotary Menggunakan Sinyal Getaran Steady State dengan Metode Rim and Face. Jurnal Teknik Mesin, 4(2), 214-223.

[10] La Oode, M. F., \& Maulana, E. (2021). Kajian Eksperimental Alat Pengering Surya Tipe Kabinet Dengan Rak Bergetar. Teknobiz: Jurnal Ilmiah Program Studi Magister Teknik Mesin, 11(1), 47-54.

[11] Haryono, A., Rubiono, G., \& Qiram, I. (2020). Pengaruh Sudut Kemiringan Ayakan Getar (Vibrating Screen) Terhadap Unjuk Kerja Ayakan. V-MAC (Virtual of Mechanical Engineering Article), 5(1), 13-16.

[12] Mustafa, M. (2011) Penentuan Frekuensi Pribadi Pada Getaran Balok Komposit Dengan Penguat Fiberglass. Jurnal Mekanikal, 2(2).

[13] J. M. Krodkiewski (2008). Mechanical vibration 436-431 Mechanics 4 Unit 2," p. 247.

[14] Mo DF, Guo-Qiu H, Zheng-Fei H, Zheng-Yu Z, Cheng-Shu C, Wei-Hua Z (2008). Crack initiation and propagation of cast A356 aluminum alloy under multi-axial cyclic loadings. International Journal of Fatigue, 30:1843-50.

[15] Maleque MA, Radhi M, Rahman MM. Wear study of $\mathrm{Mg}-\mathrm{SiCp}$ reinforcement aluminium metal matrix composite (2016). Journal of Mechanical Engineering and Sciences, 10:1758-64.

[16] Wong WA (1984). Monotonic and cyclic fatigue properties of automotive aluminum alloys. SAE Technical Paper. 